University of Louisville

ThinkIR: The University of Louisville's Institutional Repository

Electronic Theses and Dissertations

5-1909

\title{
The early missionary work of the French Jesuits in North America.
}

Edward Thomas Poulson

University of Louisville

Follow this and additional works at: https://ir.library.louisville.edu/etd

\section{Recommended Citation}

Poulson, Edward Thomas, "The early missionary work of the French Jesuits in North America." (1909). Electronic Theses and Dissertations. Paper 1147.

https://doi.org/10.18297/etd/1147

This Master's Thesis is brought to you for free and open access by ThinkIR: The University of Louisville's Institutional Repository. It has been accepted for inclusion in Electronic Theses and Dissertations by an authorized administrator of ThinkIR: The University of Louisville's Institutional Repository. This title appears here courtesy of the author, who has retained all other copyrights. For more information, please contact thinkir@louisville.edu. 
"THE BARLY MISSIOMARY WORK OF MHQ FREHCH JESUITS II IORTH AHPICA WITH SPSCIAI ATSWION GIVEN TO IHE HURON AID IROOUOIS IISSIOIS."

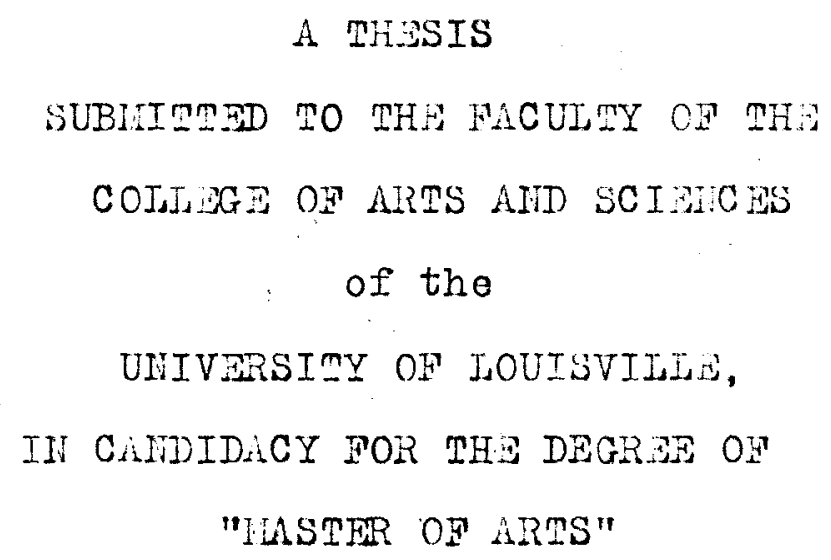

A THSSIS

SUBITIRTE TO THE FACUITY OP THS

COIJIBGE ON ARTS AND SCINCES

of the

UIIVIRSIMY OF JOUISVIIJE, II CAIDIDACY FOR THE DEGREF OY

"ILSTER OF ARTS"

\author{
by \\ EDWARD RIOIDS POULSOH \\ 1909
}


THE EARL Y MI S S IONARY WORK

$$
\text { of the }
$$

FRE I C H J ESUITS IN

N O R T H A M E R I C A,

With Special Attention Given to the Huron and I roquois

\section{Missions.}

By Edward Thomas Poulson, A.B., A.H. 
R F FE K E N C E S.

\section{$-:-:-:-$}

"The Jesuits in North America in the seventeenth Century",

By Francis Parkmar.

"Epochs of American History, 1492-1750" by R.G. Thwaites.

"The Story of Canada", by J. S. Bourinot.

"The Jesuit Relations," Vols. I, VII,X.

Bancroft (History of United States), vol.I•

"The American Nation- A Hi story," vol.7, by A. B. Hart.

"History of North America, "vol.II, by Cyrus Thomas.

"A Hi story of Canada," by Chas. G. D. Roberts.

"French Pathfinders in North America," ch. $\mathbf{x}$, by William Henry Johnson.

"old quebec;"by Gilbert Parks and C.G. Bryan,

"Harper's Encyclopaedia of United States History, vol.V.

"Narrative and Critical History of Anerica," vol. IV,P.263 If.ch.6.

"Ethnography and Philology," and

"The-Iroquois Book of Rites," in Horatio Hale. 


\section{7 \\ $-3-$}

T H E E A K I Y H I S S I ON A R $\mathrm{Y}$. W O $\mathrm{R} K$ of the

F E E N C H J E S U I T S I N

$N O K T H A$ H R I C A,

Especially Among the Hurons and Iroquois.

There are perhaps but few pesseges of history that are moro strikine than those which tell of the heroic efforts of the early French Jesuits to convert the Indians of North America. Many of these efforts are full of dramatic and philosophic interest, and they also bear strongly upon the political destinies of America. While the small young colonies of England still clung feebly to the shores of the Atlantic, events, alnost wholly unknown to them, that would eventual Iy have great bearing upon their future, were in progress in the very heart of tlie continent, the main participants being the French Jesuits and the Red Indians of North America.

Before entering fully upor the description and discussion of the early work of these Jesuits in North Arerice, perhaps it would not be amiss to speak briefly of the various Indian tribes among whom these missionaries did their work:

$$
\text { Clapter I. }
$$

The Indians of North America, their Origin,

Organization and Culture.

The origin of the Red Indian, or, rore properly speaking, the American race, is shrouded in mystery, and while they aro separate and distinct from the other groat races of manlind, yet scholars 

(in "lhe Colonies"PP.13,14.)

"The villages were little democracies, where one warrior held himself as good es enother, except for the deference naturally due to headmen of the several clans, or to those of reputed wisdom or oratorical ability. In times of war the fighting men ranged themselves as volunteers under some popular leader--perhaps a permarient chies (wolheld e position similar to the German War-Kine, losine his power in case of failure or at the end of the war.) It was this weakriess in: orenization inherent in a pure democracy, combired with their lack of self-control and steadfastness of purpose, end with the ever-prevailing tribal jeglousies which caused tine Indians to yiezd kefore the whites, who better understood the value of adherence in the face of common foe."

In art end arcilitecture they were far in advance of any of the inferior races of rankind. The statue of the great sun god in Mexico is declared by Humboldt to be one of the most sublime conceptions of wan, and though the y knew nothing of the aquare and plumbline, their great towns in Mexico, Arizona and Peru, and the'less elaborate Long-Houses of the I roquois were built with unvarying symmetry of plan and detail. Unto this day they are among the world's greatest masters in the art of pottery.

They were also skilful navigators, and their wanoes wero marvels of ingenuity, corbining strength and lightness with ease of propelling and great resistance to the action of wind and waves. In religion they were ronotheists: (Parkman's, Tho jesutt in rit,

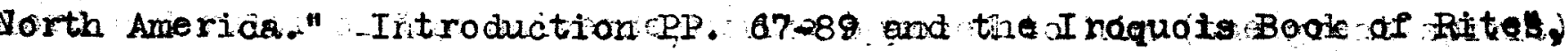
oy Horatio Hale); believing in one great spirit, lord and ruler of 
the universe, while opposed to him (the great spirit) was the ovil spirit to whom they, periaps, directed more attention than to the benificent being; because, as they said, the good spirit was too good to harm them, but unless they could propitiate the evil spirit in sone way it voula be hard to determine what injuries be might inflict upor them. The y believed in the irmortality of the soul (though the belief was of course, vague) and the resurrection of the body. They were looking for the return of what they called the white god, hence when the white men first made their oppearance among them, they were regarded oy the aivorigines as of supematural origin, or even white gods themselves.

Their so-called priests mere known as medicine men, and were for the most part cruel and tyrannical, but, as Brenton Garrison observes, "the ignorent Indian suffered no more from the tyranny of his shar-man than did the educated European from his priest;" for wherever priesthood flourishes liberty must of necessity be stifled in orler that the system may be maintained.

The position of the women was much higher among some tribes than it was anorig others; for example, Parkman (in "The Jesuits of North America,"p.xxxiii) tells us that female lise anong the Hurons had no bright side. However, in some of tine tribes the women controlled the property and had on equel voice in the tribal council with the men. To be sure their lives were toilsome, but their dangers were less then those of the men; and, after all, their position was very little worse then that of the peasant women of Europe 
today. There was a deeper family affedtion existing among móst of the tribes than we sometimes think. A good husband would undergo severe privations for his wife and children, and the children (many of them) were taught to honor and respect their parents. These wore the characteristics of rany of the tribes, and the fact that these gocd qualitios were whol Iy self-developed proves the great natural capacity of the race; for(unlike tire pooples of the old World) they had no one from whom to pottern tieir civilization.

Perhaps tine greatest family, or tribe of whom we shall have oo- casion to speak was the Algonquins, who occupied the country from Virginia to the Hudson Bay and from the Atlantic to the Great Lakes. The principal tribes of this family were the Iroquois and the Hurons. Tho Iroquois occupied southeastern Cenada, New England and Now York. As indicated by their name, they wre a confederacy of five tribes; viz, Mohawks, Oneidas, Onondageas, Cayuges, and Senecas. Their confederacy was established by Hiawatha, an Onondagas chief, about the middle of the fifteenth century. Horatio Hale tells us that while each nation was to retein its own council and manasement of local affairs, the general cortrol was to be lodged in a fedoral senate composed of repreantatives to be elected by each netion, holding orfice during good behevior, and to ke ackowledsed as ruling chlefs throughout the whole confederacy.

To tine west of tine Iroquois on the Georgian Bay of Lake Huron, lived the Hurons, a nation of ebout twenty thousend souls living in some thirty-two villages, composed of about seven hundred "long-houses," 
each of which wes occupied by 2 eens or clan consisting of perhaps a dozen or more families. These villnces were all protected by a stookade or some lake, river or hill. They were a branch of the I roquois who had become estranged from them because a Huron chief in a fit of. rage killed his I roquois wife. "This crime (of the chief) brought on a long war ween the tribes, in which war France and England later became involved, and finally ended in almost exterminating the Hurons as an independent nation.

Their foverment consisted of a confederacy of four tribes patterred after the Iroquois. The confederacy was coverned by chtefs, whose office was hereditary through the female; their power was wholly of a persuasive or advisory character (Parkman). They had two great chiefs, one for peace and one for war, but there were numerous other chiefs of lower rark. (Parkman's "The Jesuits in North America;" Int. P. 5-2-53.) These were supplemented by a council of tribal chiefs, and the unanicous consent of the latter was required to pass any measure. These tribal chiefs were elected by the vote of both the. men and the women. The transmission of hereditary possessions and honors was through the female line. If a men was killed his slayer was required to bring to the family thirty gifts, but if the victim was a woman, forty gifts were required. With the coming of the Jesuit missionaries (early in the seventeenth century,) the Hurors allied themselves with the French and the Iroquois made a treaty with the English. The Iroquois had by this time become so powerful by means of tileir leggue, or confederacy, that 
the Hurons were in constent and ia deadiy fear of them and trusted in the French to protect thom from thoir forocious onomy. This the French often did, but in doing so they incurred the wrath and etemal hat rod of the Iroquois.

So muck for tinese aifeerent tribes mong whom the Frenoh Josuits were to spend many years of arduous toil.

Those early Jesuits were no areamers; they were emphatically mon of action; action was the end of tireir existenco. Nerertheless, though strong and determined in the work tioy undertook, yet the existence of rival tribes more the Inlians was, perhaps, tho most formidable obstacle in the path of these missionaries. ("Jesuit Relations," vol.I,P.9.) Being fearful arid suporstitious of one another, the Indian naturaliy had the same feeling toward the white stranger who would chance to come among them, notwithatanding tho fact that thoy at first thought the white man was some supernatural being, and roceived him as such; but distrust and hatred soon succeeded that feeling or sentiment of are. ("The Colonies" by Thwaites,P.17.) Hence we are not surprised at the long time it took these missionarios to get even a start on their field of I abor, New France.

\section{Chapter II.}

The Arrival of the Jesuits, Getting a Start in Now France, Their Character etc.

The coming of these Jesuit rissionaries to do work among the Jorth American Indians was a very significant event. Some of them iero true, noble, consecrated men, ever seeking to do good to thoir 
 others trero not so good, in ract,}

nowly desovered fel lawmenz. thoir aims were singularly. selfish and unworthy of the cause that they claimed to represent. The first object of the best of thom was to convert the Indiens for the Indians' sake, and to establish a great branch of the Catholic Church in the wilds of America. ("irench Pathfinders in North America" by W. H. Johnson,P.147, and "Jesuit Re- . 1 lations, vol.I P.4.) There vere others, however, whose first aim was to increase the power of France. These "political priests wero well represented by suck men as the famous Fatinor AlIoney who, while he preached the goapel to the Indiens took atil. creater pains to preach the glory of the Frenciu King whose subjects he wighed to make them. This, of courge, whs only natural, since the Catholic Church had always been the mairstay of the French kings, and most ovidontiy and emphatically so just before and after the Revolution. But those who really had the missionary cause upon their heart were the ones who made a success of their work. The French missionaries of that character succeeded as perhaps no Protestant European had ever tone. These French Fethers Iived with these peoplo(the Indians) whom they were tryling to convert to christianity, shared their privations and burdens. ("desuit Relations,"vol.I P.38,39.) Hence the work of these men among the tribe's of New France must be admi red by all lovers of noble, heroic efforts. American History would: lose much of its welcone color vere there blotted from its pages the picturesque and often thrilline story of these Jesuit missionaries, who did much as explorers as well as coming on mis sions of mercy to 


\section{$\infty$

these savaje tribes. A few explorers like Champlain, Porrot and others have left valuable narratives behind thom, which are of prime importance in the study of the early French settlement in America; but it is to the Jesuits that we owe the groater part of our most valuable information conceming the frontiers of New France in the Seventeenth Century. ("Jeguit Ralations,"PP.37,38.) It was their duty and thoy faithelily perfomed it, to transmit an annual roport to their superior, which report was \& written Journal of thoir doings ("The Jesuit helations translated by Thraites.") ; it was also their duty to pay occasionel visits to their Superior. Annually (between the years 1632-1673), the superior made up a narrative of the most interesting and important erents that had occurred in various missionary districts under his charge, sometimes using the words of the missionary himself, and sometimes giving a general summary, based upon the oral report of the fathers who came to visit the Superior. (These reports are known as the Jesuit Relations, some 70 vols.)

For the most part, these weromen of trained intellect, close observers, and practical in keeping rood and accurate records of thoir experiences. They had left one of the most highly civilized countries of their times, to make their way into the very heart of the American wildemess to endeavor to win to the Christian faith one of the most savage peoples lnown to history. To gain or influence these races, it was necessary to know them intimately, come in close contact with them, find out about their habits, their manner of thought, their strong and weak points.

These Jesuits, the first students of the North American Indian, 
were not only well fitted for their undertaking, but none have since had a greater opportunity for its prosecution, and none have ever striven harder to execute their plans on the mission fields still, we cannot agree with Bancroft when he said," Not a cape was tumed, not a river enered,but a Jesuit led the may." The coureurs de bois were the actual pioneers of New Franco; $32 d$ yet coureurs de bois, for some reason or other, seldom kept a record of their travels or dolngs; hence, it is through the Jesuits that we learn of tinoir previous appearance on the scene, rot through coureurs de bois themselves. In their narration, these Jesults who were sincere and had their heart in their work never descend to self glorification, or dwell upon their almost cortinuel martyrdom; they scarcely ever compreta of their lot. We gain from their written reports a vivid picture of life in the primevel forest, as they lived it. We seem to see trem as they start out on their long canoe journeys, sitting amidst their red-3kin fellows, working their passage at the oars and helping to carry the canoe upon the portage trail; we see them made the objects of sport and scom of the savace camp, sometimes deserted in the heart of the wildermess, obliged to make their way as best they can. Reaching at last their journey's end, we often find them vainly seeking shelter in the little huts of the natives, with almost evory man's hand against them; but thoir own heart open to all men, no matter how low. We find them, when at last settled for a whilo, in some far-away village working as ageivst cope, to save the unin baptized natives from etemal death; we can see the rising storm of opposition invoked and pushed on by the native medicine-man, and at 
last the bursting climax of superstition sweep over their trembling souls. Perhaps never in any lield of labor has boen witnessod. greater self-denial and personal heroism thail theirs.

The fathers did not, of course, understand all about the Indian; their minds were much biased by the scientific fallacies of their day; but, with whatis known today, the records of these Jesuits help the student to an eccurate understanding of that untamed race of people. One writer has said tilat few periods of history are so woll illumined as the French recime in Nortin Anerica. And why so, may we ask? To whom are we most indebted for such an illumination? In a very lare measure itis due to the accurate writings or reports of those early, faithful Jesuit fathers, telling of their efforts, experionces, successes and failures in trying to save the newly-found savage races.

Cheptor III.

The: Haron and Iroquois Missions.

When Champlain had opened the way for the establishment of the French power in America, the task of baring the Chriatian faith to the red man of North America was assigned to the Jesuits; bocause the kings of France were the great supporters of the church, and the court as stipulated that the savages were to be instructed only in the laith of Rome. (Hestit, Felations," val.I P.5.) And too, it soemed ahat the Jesuit oociety, was the best fitted to carry on to success, the mission work of France's new Iy acquired territory since efforts If other missionaries had proved a failure._fesult Relations, "vol. I P. $5,6$. 
As we have already intimated, theso Jesuits beotho, tho ploneers of discovery and settIement in the new country as well as the derout missionaries to its savage tribes. The paramount objoot with most of them was, we believe, the conversion of the heathen and the extension of the catholic church; while their secondary object was to increase the power and domintion of France in the now country. Within a very. brief time after tho restoration of Canada(1636), there were a dozen or more priestg (Jesuits) in the provinco. The bold, aggressive, and self-denying Brebenf and Daniel were among them. Miseionary efforts had veen made beforo this, but they were almost a complete failure. But with the releaso of Canada to France (in 1632), the Jesuits were placed in charge of the missionary work, and right here the history of thoir sreategt missions begins. . Father Paul 10 Jeune came to Quebec on tile fifth of JuIy, and as superior he at once began the study of the language and customs of the sarages and to look over the great field about him.

On the bay of Lake Huron was erected the first mission house among the North American Indians. That first chapel, which was. called the cradie of the church, was dedicated to st. Joseph. Hero for a number of years the faithful Brebent carried on his missionary labors, enduring all manner of hardships for the cause to which he had given his life.

As tile stations multiplied in that part of the new country, the central place was given the name of st. Mary. Great success seems to have followed their efforts, and the mission awakened widespread interest in France. The king sent many beautiful and valus able presents over for tine new converts. . The pope was also well 
pleased with the progress of the work, and to strengthen and confirm these missions,plans were laid for a college in the new country of France, which was established at Quebec about two years before the beginning of Harvard College. About 1640 fontreal was taken over as missionary station, and yithin a few years the remote wildernoss all up, around the Great Lakes, as far as the Mississippi was visited by some forty or fifty Jesuit Missionarios. Hosuit Relations"vol.I P.7ff.).

About the year 1638, just six years after the history of the Josuit missions begins, the plan was conceived of establishing missions not only on the north, but also on the south of the Great Lakes, and at the Green Bay. A vast expanse of wilderness, peopled with many twber, epened the view of themissionaries, and they saw before them the great field of lawor. But it wlll be impossible to treat in this paper all the misslons opened and conducted by these Jesuit Fathers, hence we shill select two from the number.

The Huron Mission:- LeJeune and other Jesuits soon learned the difficulties of corducting missionary work among wandering, scattered hordes. Hence it was not long before they were looking most eamestly toward the vast lakes of the West where dwelt more thickly settled and stationary populations, especially the Hurons who dwelt on the lake which bears their rame. "Here was a hopeful basis of conquests;" for the Furons won over to them, the faith would spread rapidly and in wider and wider circles, embracing one by one the kindred tribes. "Parkon's "Josuits in North Averica" P.42 if.) 


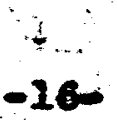

In in orfgin and language to the Iroquols mubered about sixten or twonts thousand govis. Thes dwelt in several large villeges, and thel f vrolings were bark cabins in a narrow district on the high ground between Iake 8imcoe and Coorgian Day of Lake muron. Thes wro better fighters than the Algonquins about then, but they were obliged to withdraw gradually from the Iroquois persecution, who almost exterminated them during the period of the Jesuit missions. The intelligence and mobility of the Hurons made the early prospects for missionary efforts anong them very promising. But while at first the missionaries were well received, the nqatural savagery soon asserted itself. Their medicine-men began to plot the destruction of the messengers of the new faith; the coming of diseases and raisfortunes were attributed to them; the ravages of their enemy, the Iroquois, were thought to be brought on because of their presence; they were terrified by the lurid pictures of the Judgment, and finally, an irresistible wave of superstitions frenzy led to tho destruction and blotting out of the mission, accompanied by some of the most painful scenes imaginable. ("Jesuit Relations, "vol.I P.22.) In 1615 Joseph le Carson, a Recollect friar made his way into the faraway country of the Hurons, but returned in the following year. Some five years later another of his order, William Paulin, took up the task, being joined in 1623 by the historian Gabril Sagard and sereral others. All of them, however, scon left the field save Father viel, who amid almost incredible herdships attained some degree of success; but in 1625, when descendine the ottawa to meet and arrange for cooperation with Father Brebenf at Three Rivers, ho was wilfully drowned 
by his Indian guide just back of Montreal.

About 1626, the Jesuit (father) Brebenf and Anne de None, havin received some instruction in the language from Recollets, who had been in the Huron field, proceded thither with a Recollet friar to resume tire work which had been abandoned by the Recollets. Soon, however, De None and Dailion, Brebenf's two comrades, returned to

orobes and ho (Brebent) was Iert alone. There he labored gallantly among these people, and by his easy adoption of their manners, won their hearts and gathered about him a little colony of those favorably inclined to his views. ("Jesuit Ralations", vol.I P.23.) He was recalled to Quebec in 1629 , and on his arrival was transported to Fngland, Quebec having fallen into the hands of the English. When France's lost possession (Canada) was restored to her (by the treaty og St. Germain), the Jesuits were given full charge of the Indian missions, but it was several years(about 1634) before the Huron mission could be reopened. In the following september, Brebenf, accompanied by Antoine Daniel arid Davost retumed to Brebenf's old mission field and began the greatest mission work, in the town of Ihonatiria in the history of New France. Other workers soon joined them, new missions were opened in the neighboring towns, the work was flourishing on every hand; in the cultivation of the soil and the fashioning of inplements and utensils, both for the Fathers and for the Indians, many hired laborers from the French colonies on the St. Lawrence were employed in and sbout the missions. In 1639 there was built the fortified mission house (al ready noted) of St. Mary's,to 
serve as a center for the wide-spread work, as a place for retreat for the Fathers and a refuge when the enemy pressed too closely upon them. The story of the hardships and suffering of these missionaries as told by Parknan, Shea and others, and modestly told by themselves in"Jesuft Relations," is one of the most thrilling in history. Perhaps no men have in the exercise of their iaith performed more heroic deeds than these Jesuits of the Huron Mission; and yet the progress of the work was very slow, especially for the first few years.

In the year 1642 Jogues was sent down to the colonies for some supplies for the missions, but with his Huron companions was captured by the Iroquois who led tien to the Moliowk towns. There most of his companions were killed arich Jogues was tortured and made to serve as a slave. Finally Goupel, \& companion of Jogues, and a promising young physician was killed and Jogues was rescued by the Dutch and sent to Europe. With scarcely any supplies, the missionaries were left in a bad plifht, but were finally relieved by an expedition undertaken by Brebenf and otiers.

Thus did the war-parties of the Iroquois often come upon or interfere with the Hurons snd their sympatinizers. However, in 1649 a temporary peace was formed and the hope of the Jesuits was greatiy rekindled and strengthened; for they now had about five missions in as many towns and the outlook seemed much brighter than before. But in 1648 the I roquois ettacked one of their chief villages, in which attack the faithful Daniel lost his life at the hands of the enemy. Phus he was the first Jesuit martyr in the Huron mission and the second in that country, Jogues having been tortured to death (by the 


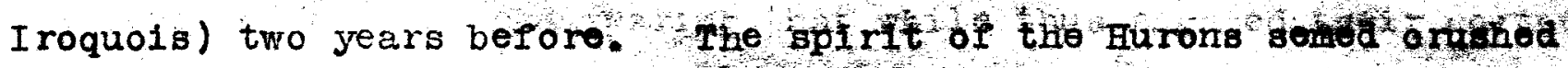
under this terrible blow, and many of them fled in terror to seor shelter among some neighboring tribes, some of them going as far west as the Green Bay and the five forests of Northern Wisconsin. ("Jesuit helations,"vol.I P.26.) Only a few towns were left, and one of these, called St. Ignatius was stormed by a thousand Iroquois in 1649 ,with only a few defenders escapin death. In Noverber Fathers Gamier and Chabanel met their death in the Petun country, Gamier at the hands of the Iroquois and Chabanel being killed by one of the Hurons who imagined that the presence of the jesuits was the cause of the great curses sent upon cis tribes.

This about ended the misaions ir the Huron coantry. A few of the remaining Jesuits followed their flocks to the isiands in Lake Huron, but in the following June (1650) the onterprise was entirely abandoned and the missionaries with a number of their followers retired to a village founded for them on tile Island of orleans, near Quebeo. nfter while this sett Iement was destroyed by the Iroquois and a final stand was made at Lorette, near quebec, which exists to the present.

The great Huron mission was conducted for about thirty-five yoars and had employed some thirty missionaries, of whom seven had died, as martyrs to the cause.

This important field forsaken, everything now seemed dark to the missionaries, and meny of themretumed to Europe., But in this hour of darkness, a new light breaks upon tize alarmed and distredsed colonies of New France. The Iroquois, being attacked by strong 
Some seven years later, during an attack upon Quebec, the I roquois captured Father Anthony Poncet and took him back to the yohamkere he suffered in the same way as his predecessors; but his captors being very desirous of a renewal of peace with the French, spared his life and sent him back to quebec, begging for renewal of peace. About the middle of the year 1654 one of the Fathers (LeMoyne) was sent forth to make an inspection of the matter, and a few months later returned to quebec with glowing reports of his splendid reception by two or three tribes of the confederacy. It. was determined to start a mission among them, beginning the work with the Onondagas tribe in 1655. The task was undertaken by Claude. Dablon and Joseph haumonot, while Le Moyne at the same time reopened a brief and unsuccessful mission among the jealous lohawks.

At first the entexprise with the Onondago seemed bright; but the natives soon became distrustful end the missionaries found it nocessary to go back to quebec and obtain new evidences of the friendship of the French. He returned in the summer of 1656 accompanied by Lellercier, Superior of the Canadian missior, and other workers and colonists under a nlitia captain, who said they were going to found a settlement in the Iroquois land.

In a short whilé tine work seemed to be in a prospering condition; some of the Christianized Hurons (who had been adopted into the confederacy) proved great assistance in the work. I roquois converts were soon made and in a comparatively short time all five of the tribes had been visited by missionaries. 
sent out from Quebec in 1657, especially for the Onondaga missions, but they had many perils en route. There had been a fresh uprising of the Iroquois against the ottawas and Hurons in which one of the missionaries lost his life, and the whole:confederacy was soon in a great uproar against the whites because of their former allianco with the ancient enemies. Le Moye joined the party late in the year(1657), and in the early part of the following year, on leaming that a plot had been made to put all the French ro death, the entire colony stole away under the cover of night, reaching Montreal on $y$ after a long and dangerous voyage.

The Iroquois mission wich had gost them so dearly erid which at first seemed to have a bright future was now thought to be something of the past. However, in the summer of 1660 , after two years of hard fighting against New France, a chief of one of the tribas came to Montreal as a peace messenger, asking for another miniater to be sent to them, especia ly for the native converts and the French captives in the Iroquois villages. Le Moyne consented to go and at once set out on what seemed to be a fatal joumey; but he fared much better than he had expected, and in the followine spring was allowed to retum home. But the raiding I roquois we re making Iife miserable in the colonies on the St. Lawrence, and it was some time before the government of New France felt itself strong enough to threaten chastisement. All of the tribes exoept the Mohawks sued for peace, but finally ticy too were driven to ask for mercy and assistance from the missionaries. (Jesuits). 



the close of the following year a misolon was in progross in ead of the five tribal districts. Some notable converts were made, but it appeared evident that great success would never be possible. The vices and superstitions of the tribes-rien were too deep-rooted, and their culture was by no means sufficient to enable them to be reached permanently with the spiritual doctrines of Christianity.

The converts were subject to so many dangers, annoyances and persecurion that it was thought necessary to put them off to themselves, a dollowing their idea, tre mission of St. Francis Xavier, opposite Montreal, was established. This settlement was subsequently removed by tile french to Sault St. Louis, and is now known as Caughnawaga. ("Jesuit Kelation", vol.IP.31.) This mission(as well

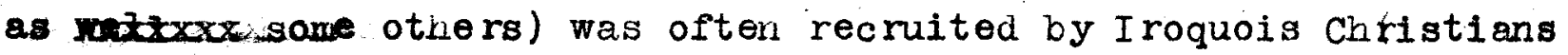
or converts who wwre carefully instructed by missionaries.

This arrangement of the removal of the Iroquois from their tribes alamed the chiefs of the confederacy. Endeavorine to please them, the Govemor of New York (hinself a Catholic) sent to the five nations several English Jesuits who sought to counteract this movement, but their efforts were in vain. The French did not abandon the Iroquois Mission until about 1687, when they were compelled to withdraw from the country because of the growing power of the English. However, there were occasionel attempts after that to revive the work. The last of the workers, however, were driven out from theneral field of the Jive Hations about 1708. After this the French Jesuits gave their chief attention to their mission 
at Caughawaga, to which place many Iroquois rotroated for safoty before the coming of the Dutch end English upon their Iands. (Parkman's "Jesuits in North America," PP.428-433.) "When the biack gowns (Fronch. Jesuits) were at last expélied from New France secular priests continued their work among the remnents of those New York Indians who had sougit protection by settline anong the French colonists on the St. Law rence." ("Jesuit Relations," vol.1;P.32.) Thus we have endeavored to describe in e brief way the beginning, development and docline of the two greatest missions conducted by the Jesuits amore the North American Indans. "The Huron mission as we have seen, caice to on end jecause of the bullits, tomahawks and general cruelty of the Iroquois, which e.Iso brought the Huron nation to an end.

"line wisdom of the Iroquois was but the wisdom of. savages. Their sagacity is not to be Jenied, but it was not equal to a ompreinension of their ows situation arid tlat of their race. Could they have read their destiny, and checked their mad ambition they might have Iinked to tzerselves those strone communities (of Indians) that would have enabled them to resist encrosclunents of the foreign power. But their organization and intelligence were merely the instruments of a blind frenzy, which impelied them to destroy those whom they might have made their allies in a common cause. (Parkm man's "Jesuits in North America,"P.434.) But it cost them dear, for in weakening and destroying other tribes they wereojeing; reduced themselves and made less able to resist the powers (Frenci and Fnglish colonists) that were soon to take full possession of their 

(about twenty or twent $y$-iive in number) some soon foll viotims to famine, haruships, and the Iroquois. (Parkman's "Jesuits in North America," P.447.) Soon Canada ceased to be a mission rield; political and comercial interests gradual ly became ascendant, and the story of Jesuit propogandism was interwoven with her civil and military armals.

The causes of the failure of the Jesuits are (some of them, at least) quite obvious.

1. They were at the mercy of the French trading companies. more and more did the fur trade assume large dimensions, and the desire for pelf, the possibility of the discovery of precious motals, Eave commercial zest to almost every undertajin. Distrust and hatred of the Indians towards the whites were naturally enkindled when they discovered how they were being treated by many of the colonists in their transactions with them.

2. The Jesuits also failed in that provision was made for the gradual setting apart from the mission of those who showed abilit and judgment to allow tinem to manage for themselves as they saw fit and proper. Tfue, toward the end of the Jesuit occupancy, the St. Francis Xavier rission(opposite Montreal) was established for certain converts amone the tribes who were subjected to many annoyances and dangers, but not because the Jesuits wanted them to think and manage for themselves independently. ("Jesuit Relation"vol.I.P.3I and"The Jesuits in North America,"by Parknan,P.431.) They wore kept too long in the place or degree of vassels, rith no incentive to 
missions were suppressed, these Indian converts, who had never beon allowed to act or taught to tinin for themselves were left in a state of helplessness.

3. A serious mistake rede by the french under tre leadership or Champlain (about 1609) caused them lasting trouble with the Indians, and was,perhaps, ore of the chief causes of their defeat in tine new world. Between Algonquins ard Iroquois tisere was unquenchable hatred. The Algorquins being the nearest neichbors of Champlain, courted their Priendship, mich wes netural, wid undertook to aid them asainst their hereditary toes." About 1609 he accompanied trem in an expedition wainst tle wowmks, one of the Iroquols tribes. A battle was fought near the sight of Ticonderoga, and Champlain wor tise victory over the astonished Mohawks, who had nover before seen a white man. This victory was a fatal one for France; because tihat day the Iroquois were made their deadly enemies, and from that day or the warriors of the Five Nations hated the French.men with an undying hatred. Besides allying themselves with the English, France's rivals in the New World, the Iroquois kept the French away from the Hudson River and prevented tiem from gotting control of New York, thus giving the Fnglish the greater advantago in the strategic part of the country. (Joun Fiske's Histry of the Trited States, "PP.54-55.)

4. Very few of the French thought of New France as their home. Unlike the English, they left their families in the old country, which made them ratier poor colonists. Dissentions at home, inferior powers oi organization, and the severty of the climate in 
that torx portion of the New World had much to do with the fallum. (Thwaites "The Colonies,"P.43 and 49.)

It is well to note the foct that the French were failuros as colonists up to the time of Napoleonif; but in modem times they have been remarkably successirul, as seen in Algiers, Tunis and Madagascar where they hove wrought wonderful changes as colonists.

- Had the French succeeded In the New World, the Jesuits would have succeeded as misslonaries. The unfortunate political and ecclesiastical policy and mismanagement at home naturally affoctod things bera. ("The colonies, "wy Thwaites,P.49,50.) Groediness, jealousies, ard price were to be found among, some of the Josuit priests as well as among the French colonists, but taking them as a class, they wero a noble, industrious, patient, heroic sot of Christianset of. men; and Modern America is today under lasting obligation to them, especially as explorers $0 \%$ t? new courtry and as splendid recordkeopers of their travels, work and experiences.

Mr. Francis Parkman says, -ard with these words we close this paper: "The guns and tomahawks of the Iroquois wer tibe ruin of the Jesuits! hopes. Could'they have curbed or converted those forocious bands, it is little less thei-certein that their dream would have become a realty. Savages tamed, not civilized, for that was scarcely possible, would have been distributed in communities through the valleys of the Great Lakes and the Mississippi, ruled by priests Inithe interest of catbolicity and of Frence. The habits of arriculture would have been developed, and their instincts of mutual 

The Josuits saw their hopes struck down; and their faiti, though nat maken; was sorely tried. The providence of God seemed in their eyos dark and inexplicable; but, from the stand-point of Liberts, , that Providence is clear as the sun at noon. Meanwhile let those who have provailed yield due honor to the defeated. Their virtues shine amidst the rubbish of error, Itke diamonds and gold in the gravel of the torrent. ("The Jesuits in North America,"by Park$\operatorname{man}, \mathrm{pp} .447,448$. 